\title{
An Orthodox perspective on hamartology and ecology: Assessing John Chryssavgis' contribution to current discourse $^{1}$
}

\author{
Dr. Newton Cloete \\ Research fellow \\ Faculty of Theology \\ University of the Free State, South Africa \\ E-mail: CloeteNW@ufs.ac.za \\ Doi: https://doi.org/10.46222/pharosjot.10246
}

\begin{abstract}
This article is a sequel to my earlier paper entitled 'Hamartology and Ecology: An assessment of Aruna Gnanadason's contribution to the contemporary debate'. Christian ecotheology presents a Christian critique of ecological destruction while also offering an ecological critique of Christianity. It entails a reinterpretation of all the classic Christian symbols, in this case the doctrine of sin, specifically the nature of sin, explored in the light of ecological discourse. Considering the contemporary ecological crisis, this article highlights Orthodox theologian John Chryssavgis' contribution to the current debate. Following a concise overview on Christian discourse on ecology, as well as the Christian understanding of the nature of sin and the ways in which it is re-described in contemporary ecotheological terms, this article explores John Chryssavgis' position on ecotheological discourse through a discussion of anthropocentrism, domination in the name of differences of species, consumerist greed, alienation of humans from the earth community as well as denial and disdain. The Orthodox tradition is an important factor in the formulation of his ecotheology. The method employed here encompasses ecclesial scrutiny, namely Chryssavgis' assessment of the Christian tradition's role in contributing to the contemporary crisis, followed by theological reflection on his interpretations of ecological sin and finally, alternative courses of action to appropriately address the issues in question. In closing, the article offers an assessment of Chryssavgis' overall contribution to current ecotheological discourse.
\end{abstract}

Keywords: anthropocentrism, domination, consumerist greed, alienation, denial and disdain.

\section{Introduction}

The entire creation is threatened by environmental problems such as deforestation, overpopulation, climate change, toxic pollution and biodiversity loss. The environment is a topic addressed in various disciplines, including Christian theology, which has shown an established interest in studying the so-called "book of nature". Lynn White's article (1967), "The historical roots of our environmental crisis", in particular sparked contemporary debates in ecological theology. According to White (1967:1206), Christianity "bears a huge burden of guilt" for ecological devastation, considering much of (Western) theology's underlying anthropocentrism supporting the notion that the world was created for human benefit. Christian theologians responded to such claims by retrieving Christianity's ecological wisdom. Others acknowledged that the Christian legacy is far more ambiguous than suggested by such apologies (cf. Santmire, 1985), and have called for an "ecological reformation" of the Christian tradition.

This article is formulated from my unpublished Masters and PhD dissertations, University of the Western Cape. 
Conradie (2006:63) observes that this task of an ecological reformation is addressed in all Christian theology's traditional sub-disciplines. This article contributes to such discourse by reinterpreting the Christian doctrine of sin from an ecotheological perspective. Christian environmental discourse commonly assumes that the ecological crisis may be understood in terms of the structural impact of human sin. Alternatively, one may suggest that the Christian doctrine of sin offers a re-description of the crisis' roots in historical, sociological, and economic terms. This calls for a basic understanding of the traditional Christian doctrine of sin - specifically the nature of $\sin$ - and its ecotheological interpretations.

The origin of sin, the relationship between sin and demon possession, the relationship between sin and suffering, the notion of original sin, the knowledge of sin, and the nature of sin, as identified by Durand (1978:9), are six themes addressed in current discourse on sin. The Christian tradition defines the nature of sin in diverse ways. In classic terms, it may be described as pride (superbia), the human desire to be like God and the rejection of His divine superiority as Creator; greed (concupiscentia), a state of continual discontent, particularly with regard to material wealth; moral failure (hamartia) or "missing the mark"; "hydra"2, implying the mutation of sin from one form to another; or sin as deprivation of the good, having no ontological status and only describable in negative terms, for example nothingness or a broken relationship with God (Heyns, 1978:175-178; Williams, 1985:198-204; Barth, 1958:102; 1960:349-355; Engel, 1990:163; Niebuhr, 1996:186-188, 228-230, 240).

These narratives have been reinterpreted and redefined in the context of ecological threats, described here as "ecological sin", or "human failings ... to relate to non-human creation in ways informed by justice and peace" (Horrell, 2010:134), which may be classified into various (often overlapping) categories. Anthropocentrism assumes humans are the most superior creature and nature exists for the sole objective of serving human purposes. Such assumptions typically serve to condone domination in the name of differences of species. Consumerist greed implies dissatisfaction with current possessions and a desire for more. Sin stems from estrangement and broken relationships, expressed as alienation of humans from the earth community, meaning disaffection for the "other" - nature - and other living beings. Sloth implies moral failure, backwardness or lack of development. Folly suggests a lack of wisdom, and denial entails refusing to accept the reality of the ecological crisis (Cloete, 2013:58-107; Conradie, 2017:29-60; 107-175).

A multi-stakeholder and multi-contextual approach is required to address the ecological crisis by considering various contributions to contemporary discourse and how scholars from diverse geographical, confessional and socio-political contexts, genders, races, classes, etc. are influenced by such factors and respond to the crisis. This article contributes to such literature by retrieving insights from Orthodox theologian Rev (Dr) John Chryssavgis. As a Professor of Theology at Holy Cross School of Theology in Boston, USA, and Religious Studies Program director at Hellenic College, he also founded the Environment Office in 2001. His publications include several books and numerous articles in the area of religion and ecology, as well as social justice and peace.

\section{Anthropocentrism}

According to Chryssavgis (2019:160), human sovereignty over nature is regarded as being authoritative. Judeo-Christian tradition rooted, this idea influenced the Hellenistic age, and ultimately Western thought ${ }^{3}$. He cites White (1967: 1205): "[E]specially in its Western form,

\footnotetext{
2 A popular Christian notion is the "seven deadly sins", including pride, wrath and envy (spiritual sins), and greed, lust, gluttony and sloth (corporal sins) (Aquinas, 1991:268).

3 'Dominion over nature' in Eastern thought revolves around "contemplation" (theoria), often involving legends of wild animals and natural elements working with and for the desert dwellers, and humans as
} 
Christianity is the most anthropocentric religion the world has seen". The biblical term "stewardship", or rather contemporary interpretations thereof, encompasses domineering, prideful undertones and historically advanced the notion that humans - superior to the rest of creation - are the only creatures worthy of salvation (Chryssavgis, 2019:155-156).

Chryssavgis (2019:111) holds that the ecological crisis is the result of a wrong path taken since "the beginning": the idea of humans made "in the image and likeness of God" (Genesis $1: 26$ ) is unduly emphasised while the notion of formed from "the dust of the ground" (Genesis $2: 7$ ) is ignored. The sixth day is not an exclusive dedication to humankind making, but rather a day shared with "living creatures of every kind" (Genesis 1:24) (Chryssavgis, 2019:137; 2003a:23). The church's mandate is calling humans to "conversion from autonomy to dependence on God, from independence to ecclesial communion, from anthropocentrism to theocentrism" (Chryssavgis, 2007:18-19), and holding us accountable as prudent, faithful stewards (Luke 12:48) (Chryssavgis, 2019:153-154).

Chryssavgis (2019:153) states: "Anthropocentrism is an entrancing temptation to which we are all guilty of submitting at one time or another, and which has detrimentally burdened our perspective and practice". The natural environment is considered a mere stage where the more significant human drama plays out (Chryssavgis, 2019:96; 2006:99). We falsely believe we are in control of ourselves and the world around us (Chryssavgis 1994:91), yet we are relentlessly trapped within our individual desires and the need for self-preservation - with tragic consequences (Chryssavgis, 2007:3; 2017:274). In the view of Chryssavgis (2017:274; 2007:3) we humans disregard the grace and dignity with which the world is endowed: "Our generation ... is characterised by a sense of self-centredness toward the natural cosmos, by a lack of awareness of the beyond" (Chryssavgis, 2019:113; 2010:217). He ponders whether our lack of empathy for the earth stems from our notion of a de-divinised cosmos (Chryssavgis, 2019:34), or perhaps of our human insecurities (Chryssavgis, 2019:7; 2017:8).

Chryssavgis (2007:168) calls us to acknowledge that we are responsible for creation's shattered image, noting: "We are not the good Samaritans, but the highway robbers" (Luke 10:29). It is self-righteous presuming that we have cared for this world while we fail in transforming God's creation by narrowing life to ourselves (Chryssavgis, 2019:122). Even narrowing religious life to our concerns and desires implies a lack of faith to implore God's grace for creation's renewal (Chryssavgis, 2019:146; 2017:278).

\section{Alternatives}

Chryssavgis (2019:123-124; 2003a:30) proposes self-denial to overcome self-centredness through contemplation of the cross, resulting in liberation from egocentrism. Instead of living in supremacy over creation, we should respect creation as manifestation of God's love (Chryssavgis, 2017:274), endowed with His living traces (Chryssavgis, 2010:222). Chryssavgis (2019:63) believes pride can be overcome with humility through simplicity. All human beings constitute God's living temple and the entire creation His altar (Chryssavgis, 2019:73; 2007:146). He states: "If one can visualise the activity of the Spirit in nature, then one can also perceive the consubstantiality or cosmic interconnection between humanity and nature; then one would no longer envisage humanity as the crown of creation, which it is charged or entitled to subdue" (Chryssavgis, 2019:94; 2007:36).

Restoring the world's shattered image requires a change towards traditional ways of thinking and a retrieval of ab-original spirituality and mythology (Chryssavgis, 2017:282-283; 2007:12). Chryssavgis (2017:277) hereby draws from Isaac the Syrian, stating that "a merciful heart ... burn[s] with love for ... all God's creatures [and] smashes the self-centred, secular world-view

"the Creator's partner" or "creation's protector". The concept of "work" (labora) in Western thought assumes human rights over nature, allowing increased manipulation and exploitation of resources by humans as governors driving and controlling nature (Chryssavgis, 2019:161-162). 
and gives us a sense of enlarged existence". We move beyond our own to experience other dimensions of life, seeing the world as integral part of us. Thus, there can never be a sharp distinction between humankind and nature as all creation bears the divine's imprint and likeness (Chryssavgis, 2019:3). We should not withhold from nature the sensitivity and tenderness we would offer to human beings (Chryssavgis, 2019:145; 2003a:28). Setting ourselves up against or over the rest of creation establishes disparity and distinctiveness (Chryssavgis, 2019:6). Chryssavgis (2019:120) states "it would be more accurate to say that we actually are creation, that we are truly the cosmos", as the created world will be transformed and presented to God through human beings. He quotes Metropolitan bishop John of Pergamon: "[l]n doing this 'in Christ' we, like Christ, act as priests of creation. ... This distinguishes ... and attaches to the human being an awesome responsibility for the survival of God's creation" (in Chryssavgis, 2019:120).

In contrast to a superior role, Chryssavgis (2019:4) portrays humankind as the centre, the meeting point of all of creation - "a bridge of union or point of contact"; a microcosm and universe in itself, and simultaneously "a mediator, a bond of sorts - integrating and reconciling the fragmentations within oneself and the divisions within the world". It would be most humble and helpful to acknowledge that we are eternally united with God's world (Chryssavgis, 2019:113). Salvation is not restricted to humanity; it is social and ecclesial, universal and cosmic (Chryssavgis, 2007:168): "The whole of creation has been groaning together in pain until now, inwardly awaiting its liberation by the children of God" (Romans 8:22-23).

Chryssavgis (2007:21) reiterates the Christian calling: to be trustworthy caretakers and faithful stewards of creation, as through "remaining faithful to the earth ... the Church also becomes new heaven" (Revelation 21:1). In this we realise the Church Fathers' vision of oikonomia - a dynamic concept of revelation and salvation - to nurture and safeguard creation to serve and save it (Chryssavgis, 2019:155). Because traditional understanding of "stewards" or "custodians" might be misleading or misinterpreted, Chryssavgis (2019:156) suggests using pastoral terms like "farmer" or "shepherd", or alternatively in liturgical language, "priest" or "mystic" to more accurately describe humanity's role in God's service.

\section{Domination in the name of differences of species}

Chryssavgis (2019:152-153) maintains that the creation of humankind to "till and keep" the earth (Genesis 2:15) can be translated as "to serve and preserve it", yet the biblical term 'dominion' has been misinterpreted as "domination in an unashamedly self-centred and selfserving manner". The command in Genesis 1:28, "Be fruitful and multiply; and fill the earth and subdue it; and have dominion over ... every living thing", licensed abuse and exploitation of the natural world throughout history (Chryssavgis, 2019:111; 2007:53). According to Chryssavgis (2019:152), the notions of 'short-term dominion' and 'self-centred mastery' apparent in Genesis 2 make it plausible that it is "our God-given role to reap and rape the earth without a long-term vision". All earthly activity is interpreted in the context of the final rapture of the Messiah's return, consequently fading into insignificance. This mindset warrants unlimited wealth acquisition, reckless abuse of power and oppression of others.

Chryssavgis (2019:113) believes we are called to affirm the creation of humans on the sixth day for the purpose of sharing the earth with all other creatures, and states: "Anything less than the full story ... of that sixth day of creation is a heresy". He refers to White (1967:1207) who disapproves of the Judeo-Christian tradition for supporting wilful exploitation of the natural environment: "[W]e shall continue to have a worsening ecologic crisis until we reject the Christian axiom that nature has no reason for existence save to serve man" (Chryssavgis, 2019:157-158). Chryssavgis (2019:158-159) highlights the distinction White makes between attitudes towards nature in the Eastern and Western Christian traditions: 
What I have said may well apply to the medieval West, where in fact technology made spectacular advances ... The implications of Christianity for the conquest of nature would emerge more easily in the Western atmosphere.

According to Chryssavgis (1994:82-83), our treatment of nature is grounded in how we treat ourselves and other humans. Creation is devalued, because we progressively separated divine grace from both the natural environment and our human nature. Jesus' Eucharistic words, "Take, eat, this is my body ... drink of this my blood all of you" (Matthew 26:26-28), is understood as license to exploit creation, including human beings. As Paul states, we have "exchanged the truth ... for a lie ... and the natural use of things for an unnatural abuse" (Romans 1:25-27) (Chryssavgis, 1994:87-88). It is therefore not surprising that sin and abuse are rife in and often caused by an institution usually identified with grace: the church (Chryssavgis, 1994:89).

Chryssavgis (1994:89-90) believes abuse of institutional authority arises due to discrepancy between the church's charismatic element and sinful expression of its structural power, between divine grace and sinful institution. The church abuses its grace dimension, surrendering to sin and inflicting suffering onto people. This represents spiritual abuse: submission and obedience merit communion of grace, while exposure and disobedience are threatened with ex-communication or 'falling from grace'. Sharing the domineering and exploitative character of environmental and physical abuse, spiritual abuse differs in not causing bodily or earthly bruises, but permanent scars on the church's body and human souls. Rather considered an energy that can be disciplined and redirected, sin becomes something for which people are disciplined; rather discerned by people, grace is determined for them.

It is inherent for humans to often reduce others to inferiority, whether in our relationships with fellow humans or other creatures (Chryssavgis, 1994:88). Environmental concerns such as climate change, global warming, deforestation, soil erosion, extinction of fauna and flora, and pollution thus inevitably became pressing issues. Chryssavgis (2019:163-164; 2010:215-216) affirms that such crimes committed against the natural world implies sin in the same manner as crimes committed against humans.

According to Chryssavgis $(2019: 97 ; 2006: 99)$, the disenchantment of nature is the precondition for the development of science, leaving the natural environment vulnerable to human abuse. He states: "We treat our planet in this god-forsaken manner precisely because we see it in this way" (Chryssavgis, 2019:130; 2003a:23). Continuous violence against natural inclinations leads to "the inevitable ... rape of nature around us" (Chryssavgis, 2019:75; 2007:149).

Chryssavgis draws from Berry (1991:48-49) who believes our inter-human relations and our relationship with the earth are interlinked: damaging and exploiting the one implies harming the other, conforming to the same conditions and means (Chryssavgis, 2019:5; 2017:276). Presently do not heed scientists' call to conserve at least half of Planet Earth. Rather than honouring nature as a sacred presence to be "loved, transformed and venerated", we regard it an objective reality to be "examined, experimented and exploited" (Chryssavgis, 2007:2).

Illustrating the latter, Chryssavgis (2019:58-59) notes that ruthless urbanisation and natural resource exploitation lead us to either romanticise or resist the notion of 'wilderness'. Earthy areas are commonly associated with the poor and destitute, while the affluent prefer city balconies and vistas. Chryssavgis (2007:67) highlights our distorted perception: "[H]uman reason decides upon the relatedness and relevance of the various parts of the world; and human reason uses and abuses creation through domination". We have ultimately become victims of our own compulsive needs. Sin effects distortion and division, and we plunge into a lifestyle of spiritual death and cosmic ruin (Chryssavgis, 1994:82). Like the servant in the parable who is called to accountability by the Master (Luke 16:2), we too will face judgement for devastating the earth, unjustly distributing resources, as well as controlling, manipulating and exploiting the poor (Chryssavgis, 2019:154). 


\section{Alternatives}

For Chryssavgis $(2019: 112 ; 2007: 53)$ it is imperative that so-called dominion scriptures be interpreted in the light of creation care. 'Dominion' does not imply a license to dominate and exploit, but "ruling in accordance with the love, peace and justice of the Creator" (Chryssavgis 2019:153). We fail our God-given commission of being true stewards when treating the earth as wasteland and disregard being its voice, ears, eyes and conscience. Discerning the Creator in the world is an essential element of being created in God's image (Chryssavgis, 2019:112).

Chryssavgis (2019:157) describes the faithful steward as one who upholds creation's sacredness. Governed by care and humility, the person thrives on giving thanks, selflessly serving others, sharing the planet's resources and being satisfied with their portion (Chryssavgis, 2003b:73). "Such a person stands at the intersection of a sacramental worldview and a sustainable way, subsisting as a vessel of gratitude and grace". Ultimately, as Chryssavgis (2019:113) affirms, authentic care is about truly honouring creation, "of hearing 'the groaning of creation', about affirming the truth of that sixth day of creation".

Concerning spiritual abuse, Chryssavgis (1994:90) challenges church leaders' notion of possessing authority to "communicate" or "withhold" grace, which ultimately comes from God. He notes, "[T]he call to grace is a call to a life of caring and sharing". Respect and responsibility are essential to the aversion of power abuse by those in authoritative positions. Churches should thus actively advance leadership fostering love and communion, and moreover be consciously aware of its own sin to enable the flow of divine grace.

Respect for creation implies caring for human beings and nature (Chryssavgis, 2019:176177). Chryssavgis (2003a:28) stresses a balance between water and land rights, as well as human rights, arguing that nature should be afforded the same healing and restoration space as reparation, reconciliation, and rehabilitation of human communities. He states: "[P]erhaps what we are called to is not so much acquire or produce something for the planet, but rather to relinquish and surrender something to our planet" (Chryssavgis, 2019:176). For Chryssavgis (2019:57), the Desert Fathers and Mothers' example is an excellent reference point in acknowledging that creation is not ours to dominate and exploit, but rather a sacrament.

\section{Consumerist Greed}

The appeal to challenge or abandon wasteful lifestyles frequently arises in non-religious circles (Chryssavgis, 2019:132) compared to traditional religions and institutional churches that are less receptive to adopting simpler lifestyles. Christians in particular are often "the primary culprits for the scars on the beauty of ... the body of the world" (Chryssavgis, 2007:64; 2006:111). Chryssavgis (2017:274; 2007:4) states: [T]he 1,5 billion followers of Jesus ... now control two thirds of the earth's resources and, on average, are three times better off than their non-Christian neighbors." He further comments that these very Christian followers are prominent for deep ecology thinking and opposing racist and other oppressive systems while condoning economic inequality (Chryssavgis, 2007:4; 2017:274-275). In Chryssavgis' view creation should never be confused with the Creator, whom should always be envisaged in and through creation (2019:163). He challenges religious thinkers and communities to define this relationship correctly, which may otherwise lead to an incorrect view of sin and free will, as well as greed and ascetism, distorting the relationship altogether.

Sin is a matter of choice - either sacrifice or self-centredness and individualism - involving the desire for private liberty and possessions, flowing from a distorted understanding of free will. Such libertarian theology and covetousness contradicts the Christian Gospel and religious ascetism, which curtails avarice, greed, envy, and lust - the driving forces of free trade and the market economy (Chryssavgis, 2019:165-166). Chryssavgis (2019:169) describes the free market as a domain "where great predators roam and the law of the jungle reigns ... [with] 
hardly an expression of fairness or philanthropy". He condemns its dazzle for blinding people and deforming their worldview, making them oblivious to deeper connections. Humans are considered mere consumers. Ultimately it involves free will and choosing between greed and grace.

Chryssavgis (2019:169-170) holds that creation is a divine gift, while politics and economics are man-made. He criticises libertarians for casually adopting "stewardship" and adapting the biblical mandate of "creation care" while advancing their own political agendas of land appropriation and exploitation. The market and its dominant preferences are not interrogated, supporting the passions of profit and personal pleasures. The "great driver, and at the same time great donor" is the global corporate or multinational way of thinking. Oil magnates and large corporations often fund think tanks that follow the unchallenged market economy and, resultantly, manipulate public policy makers. Chryssavgis (2019:168) offers a striking example of how even world leaders promote a consumerist culture and recalls President Bush's response to the 9/11 terrorist attack. The entire USA nation waited in anticipation for his answer to the question, "What is expected of us?" He describes his personal experience of this event:

I thought he might perhaps advise ... 'Read the Bible!' 'Attend church!' or simply 'Fast!' Instead, he advocated: 'Go shopping and spend money, go out and travel ...'

Chryssavgis (2019:168) provocatively asks: "Have we honestly become so addicted to fantasies about riches without risk and profit without price? Do we honestly believe that our endless and mindless manipulation of the earth's resources comes without cost or consequences?" He comments that our "economy and technology are toxic when divorced from our vocation to see the world as God would" (Chryssavgis, 2019:172). In modern times productivity has become the norm and everything is measured in consumer value (Chryssavgis, 2019:98; 2007:43). Gratifying the irrational, insatiable desire for a given commodity - produced at the lowest cost and at any expense to the common interest - drives consumer society activity (Chryssavgis, 2019:172). We treat creation "like a Ponzi scheme where individuals or corporations withdraw resources but never deposit replacements, always with the false assurance and immediate gratification of new investment" (Chryssavgis, 2019:177).

In referring to an ascetic lifestyle opposing urbanisation and related cycles of production and consumption, and ultimately destruction, Chryssavgis $(2019: 54 ; 2007: 118)$ cites Basil the Great in stating that "not everything was created for the sake of our bellies". Chryssavgis (2019:125-126) believes that food and its associated vices of gluttony, greed, waste and apathy constitute the most prominent contributor to economic injustice and ecological exploitation. Considering hunger experienced by the poor and deprived, he maintains the problem is not overpopulation, but rather the method of food distribution: through the market and as private property - unaffordable to the masses. He cites Berry (2009:281), who holds that food is a sacrament of communion - sharing in the flesh of the world:

To live we must daily break the body and shed the blood of Creation. When we do this knowingly, lovingly, skilfully, reverently, it is a sacrament. When we do it ignorantly, greedily, clumsily, destructively, it is a desecration (in Chryssavgis, 2019:126-127).

Chryssavgis (2019:125) holds that everyone is in one way or the other guilty of consuming the earth's resources far in excess. "No matter how careful modern man has sought to foster material prosperity and self-sufficiency, it is now clear that grave 'fissures' and 'faults' have appeared on the face of the earth" (Chryssavgis, 2019:1; 2017:1). People reluctantly forego profits or alter their consumption habits. After all, capitalism's core aim is providing motivation to acquire more and live more luxurious lifestyles. Ultimately, it amounts to choosing between profit and principle: "You cannot serve God and Mammon" (Luke 16:13) (Chryssavgis, 2019:172). 


\section{Alternatives}

Chryssavgis (2010:222) believes humility and simplicity makes earth preservation possible. The icon of hospitality radically opposes the icon of greed, and inspires us to relinquish selfish desires, "so that, everyone seated at the table may have equally full plates" (Chryssavgis, 2019:128). Apart from the earth's economic value, making it a mere object of exploitation, it also possesses moral and sacramental value, bearing the very presence of God (Chryssavgis, 2007:139)

As mitigation for market dazzle, Chryssavgis (2019:169) suggests we look to the cross, symbolising sharing and sacrifice. We should relearn generosity, fairness, compassion, and communion - essentially relearn the value of ascetism. He quotes Patel $(2009: 3,22)$ who states: "What needs to be plucked out of markets is the perpetual and overriding hunger for expansion and profit that has brought us to the brink of ecological catastrophe [and] the belief that markets are the only way to value our world" (in Chryssavgis, 2019:171).

Chryssavgis $(2007: 64 ; 2006: 110)$ is of the opinion that the Orthodox concept of ascetism should be considered as practical solution to overcoming material desire. In his words, ascetism is "a social event; ... a communal attitude that leads to the respectful use of material goods". It implies spiritual development, yet not violating others' personal limitations, or terrestrial development, and not surpassing environmental sustainability. Ascetism avoids "the desire of the flesh and the lust of the eyes and the pride in riches" (1 John 2:15-16) (Chryssavgis, 2019:65) and includes disciplining our daily lives with regard to consumption, greed, and compassion (Chryssavgis, 2019:177; 2006:110-111). It further entails being free not in abusive ways towards the world, but guided by self-control for the purposes of refinement and restoration. Ascetism creates self-awareness to achieve moderation, for oneself and the rest of the world. The Christian concept of "fasting", for example, limits consumption and the intake of food, and enables joyful sharing, living for communion and recognising God in the world (Chryssavgis 2019:124-125). The Eucharist, in addition, challenges both communities and individuals to work towards a just society with sufficient resources for everyone (Chryssavgis, 2019:92-93).

Another ascetic principle highlighted by Chryssavgis (2019:178) is "detachment": giving up destructive lifestyle choices, including consumption habits. It "becomes a surrender of greed and a school of grace". We learn what is truly worth holding on to and "shed excess luggage in order to travel and tread more lightly ... with far less than we can imagine". Ultimately we are liberated to focus more on God and others and less on ourselves. Adopting a spirituality of detachment might not be easy since we are culturally conditioned to believe that having more means being better off. The desert fathers and mothers' lifestyle, however, teaches us the opposite: the less you have, the more you can be.

\section{Alienation of humans from the earth community}

Chryssavgis $(2019: 29-30 ; 2007: 73)$ considers the views of familiar patristic fathers that significantly influenced Christian practices and contributed to dualistic attitudes: Clement of Alexandria's worldview does not incorporate the basic Christian principle that the truth became flesh and dwelt in the world. Origen of Alexandria's attitude toward matter and history is considered problematic, because the soul is perceived as being imprisoned by the body. Encounters with God in the world are mere glimpses in contrast to the spiritual, heavenly realm: "The human mind should mount to spiritual understanding, and seek the ground of things in heaven". Likewise, for Plotinus of Alexandra matter represents "nothing", is without form or shape and similar to the chaos out of which the world was created (in Chryssavgis, 2019:31-33).

According to Chryssavgis (2019:165), sin has always been "reduced to a list of transgressions or misdemeanours before a sadistic, stringent father somewhere in the distant heavens" 
instead of being regarded as a breakdown in relationships. He refers to Dawkins (2006) who states that the Christian focus is overwhelmingly on sin, and consequently "[s]in fatigue has led to a dilution and demolition of the notion of sin" (in Chryssavgis, 2019:165). Theologians are inclined to emphasise sin's individual implications, yet the ecological crisis is a reminder of its cosmic consequences, not limited to the spiritual, psychological, or social dimension. Every act of pollution, destruction, or exploitation against nature counts as an offense against the Creator.

The primary reason for abuse of institutional authority by the church - the communion and excommunion of grace - is the sharp distinction drawn between sin and grace, argues Chryssavgis (1994:89). Sin supposedly characterises the world, while the church seemingly possesses grace and authority to exercise control over grace. Such religious thought and practice arose particularly during the Middle Ages. People were either unable to overcome this dichotomy, or entirely failed in differentiating between the sacred and profane. This thinking still prevails and reflects in the lack of confidence in the church (Chryssavgis 2007:16). The identification of grace with church representatives leads to abuse of authority and confusion, as grace - a divine gift - is reduced to the institutional limits of the church (Chryssavgis, 1994:89-90). Chryssavgis (2007:21) heeds that failing to recognise the interdependence between the church and the world, and overemphasising the church as "a new creation" or as "the world transfigured", result in people only perceiving the otherworldly element of the church. This distorted understanding of grace and sin, and the church and the world advances the belief that salvation is not intended for God's entire creation, ultimately leading to alienation.

Chryssavgis (2019:96-97; 2007:41-42) believes that modernity's detachment from and lack of regard for creation indicates indifference towards the world and also unwillingness to partake in its "pain and suffering, pollution and ugliness". When salvation is separated from the rest of creation the cosmic integrity and the iconic view of creation are lost (Chryssavgis, 2019:116). He highlights the apocalyptic view, where nature is perceived as just a mere stage for the more important human drama. It orders escape from the natural created order and condemnation of humans that flounder in this "inferior" creation, based on the belief that salvation is destined for only "the few". A meagre band of human experience is regarded sacred while the rest is relegated to profaneness (Chryssavgis, 2019:96; 2006:98-99). Chryssavgis (2019:94-95), however, argues that God cannot be perceived in heaven if His presence is not recognised in the beauty of a forest, the density of a city, and also in the sand of a desert. He emphasises Berry's (1991:16-17) images of the otherworldly and the touristphotographer, whom in his opinion both lack appreciation for the "mystery and immensity" of God's creation. The former focuses on the afterlife, while the latter only values the world through images captured - both not comprehending the present beauty and mystery of God in creation (Chryssavgis, 2019:88-89; 2007:30-31). Berry (1991:16-17) is cited, saying:

[T] he tourist photographer ... will never know where he is, but only, in looking at his pictures, where he was. ... Looking through it, he is not likely to see anything that will surprise or delight or frighten him, or change his sense of things. ... He is blinded by the device by which he has sought to preserve his vision. He has in effect, been no place and seen nothing ... (in Chryssavgis, 2019:88-89).

It is clear that we "are no longer respectful pilgrims on this earth; we have become ... mere tourists" (Chryssavgis, 2019:119; 2003a:27). Chryssavgis (2019:112) calls us to never allow our "heavenliness" to overshadow our "earthliness". According to the creation story, humans have no claim to any of the days like other creatures, as they shared the sixth day with all other creatures. Chryssavgis $(2019: 112 ; 2006: 105)$ draws attention to Adam naming the animals (Genesis 2:19-20), referring to it as a lasting, loving bond between humankind and the environment, as well as the Creator. He attributes the radical de-divinisation of the world to our inability to attain communion with God. Through our treatment of the earth as wasteland we fall short of our vocation to responsibly care for creation, recognise God in the world, and 
living up to being His image and likeness. We disconnected the world from heaven and as a result desacralised both, violating the sacred covenant between Creator and creation (Chryssavgis, 2019:114; 2010:217). It is indeed apparent that sin brings about a schism in relationships, desecrating the natural order of creation (Chryssavgis, 1994:83).

\section{Alternatives}

According to Chryssavgis (2019:43), the Eastern Christian tradition does not perceive the traditional dualisms in Scripture, for example between spirit and matter, grace and nature, or Scripture and creation, otherwise prevalent. He believes humans are called to discern God's being in all of creation, and refers to St. Ephraim the Syrian who states: "Wherever you turn your eyes, there is God's symbol ... Look and see how nature and scripture are linked together". Christian wisdom theology also teaches that all things bear the seed of God: "The world is in God, despite the fact that it exists outside of God. The world belongs to God, in spite of being wholly other than God. Such a worldview is neither dualism nor pantheism, but Christian panentheism or immanentism" (Chryssavgis, 2019:74-75; 2007:147-148). Chryssavgis $(2019: 5 ; 2017: 276)$ notes that this also reverberates in Origen of Alexandria's philosophical thought: "The world is like our bodies. It, too, is formed of many limbs and directed by a single soul. Yes, the world is an immense being directed by the power and the word of God, who is, so to say, its soul".

Chryssavgis (2019:23) suggests rather than focusing on making distinctions, discussions on the relationship between the church and the world should emphasis the role of divine grace, the fundamental and transformative dynamism of renewal, as well as restoration in Christ. The ascetic worldview acknowledges that every element of creation is mutually interdependent and intimately interconnected, reflecting the fragility of the world in its wholeness (Chryssavgis, 2019:179-180). This also holds true for the church and the world: "The Church then is the world, as the latter was intended to be. And the world is the Church, as the former is called to become" (Chryssavgis, 2007:21).

Accordingly, the earth is then our very flesh. As the Apostle Paul points out in Ephesians 5:29, a person cannot hate their own flesh (Chryssavgis, 2019:5; 2017:276). As opposed to dualistic thought, nature and humankind are profoundly connected (Chryssavgis 2019:162). Chryssavgis (2019:180) refers to Bartholomew, whose environmental ministry throughout reflects the sacramental worldview: "the planet and all people as the incarnate body of the Creator, an inseparable and interconnected part of the living God".

The same principle also applies for understanding the link between heaven and earth; between the spiritual and the material. Chryssavgis (2019:117) maintains that the icon - the way we ought to view creation - does away with any "objective" distance between the two:

\footnotetext{
Indeed, the world ceases to be something that I observe objectively, or exploit selfishly, and instead becomes something of which I am a part ... No longer should I feel as a stranger ... but as a compassionate friend in and of the world (Chryssavgis, 2019:117; 2007:21).
}

Chryssavgis (2019:75-76) thereby identifies the cosmic interconnection of all created things profoundly connected to the Word and belonging to God. Just as God saw the world was good, we are called to perceive its beauty (Chryssavgis, 2019:172). Cosmic reconciliation entails reconciling in humility our relationship to others and God (Chryssavgis, 2019:6). The icon enables restoration and ultimately cosmic reconciliation, reminding us of a heavenly kingdom revealed in all of us (Chryssavgis, 2019:114).

Chryssavgis (2019:92-93) draws attention to the seven Orthodox sacraments, infusing "the hearts of those open to the possibility of encounter with God". Baptism symbolises the human recreation, immersed into Christ's death and resurrection. Chrismation recognises the Holy Spirit indwelling in every created being. The Eucharist intensifies our sense of communion. Confession opens channels of grace and healing, and reconciles us to God and creation. 
Marriage is an expression of love and communion, of bridging separation and isolation, and symbolises unity. Holy unction is an outpouring that heals brokenness and the breach between soul and body, and mends the shattered parts of our hearts and the world. Through ordination the whole world becomes a cathedral for God's kingdom. Chryssavgis (2019:93) comments that the sacramental principle enables us to recognise God's presence in His entire creation, thereby triumphing over all forms of alienation. In the sacramental worldview everything is unique, assuming its singular purpose and place; yet, everything becomes sacramental, takes on a Christ dimension, and depends on our hearts' openness and receptiveness (Chryssavgis, 2019:115).

\section{Denial and Disdain}

Over time scientists issued prophetic warnings regarding the disastrous effects of environmental destruction, and based on this some theologians are increasingly calling for environmental preservation. Another small group of scientists dispute the scientific majority's claims, and some religious leaders then use this as basis to downplay the prophetic warnings (Chryssavgis, 2019:135). Chryssavgis (2019:149) remarks that "human beings are sometimes less prone to rapid conversion than ... tectonic plates are to sudden shifts", hence many religious institutions are also either "traditionally" sluggish or extremely stagnant to acceptance or adjustment. This might be why religious leaders are often challenged with an unrealistic burden of hope and why climate deniers and disdainers find it difficult to accept that religion contributes to the problem.

Religious leaders are also guilty of undermining and denying the presence of sin on the church's institutional level. It is (falsely) believed that sin cannot be identified with the church - the so-called "communicator of grace" - but only with the world (Chryssavgis, 1994:89). Chryssavgis (1994:90) comments, "[P]ower has a way of blinding the conscience". Church leaders often deny their role in spiritual abuse, claiming to act in the name of "ordaining grace" while advancing their own convictions. Refusing to recognise sin essentially amounts to a loss of grace, resulting in a "hardening of heart" (Hebrews 3:8) and "an interlocking of sin, whereby sin becomes established from generation to generation" (Chryssavgis, 1994:90).

Similarly, the Christian tradition is blameworthy for not timeously identifying environmental sin. As Chryssavgis (2019:163-164; 2010:215-216) observes, Bartholomew was the first religious leader to explicitly link environment harm with sin, contained in his 1994 encyclical. Only three years later it was publicly stated:

To commit a crime against the natural world is a sin. For humans to cause species to become extinct and to destroy the biological diversity of God's creation ... degrade the integrity of the Earth by causing changes in its climate, by stripping it of its forests, or by destroying its wetlands ... for humans to injure other humans with disease and contaminate Earth's waters, land and air with poisonous substances ... these are sins.

Chryssavgis (2019:174) maintains that deniers and disdainers misconstrue the meaning of ascetism, arguing that it denies people creation's benefits. They advocate the Gospel commandment to "seek first the kingdom of heaven"; yet narrowly interpret it in the subsequent clause, namely "all these things on earth will be yours as well". It is therefore not surprising that White's critique of Christianity's role in our worsening ecological crisis is "ruthlessly denounced by climate deniers and disdainers" (Chryssavgis, 2019:158-159).

According to Chryssavgis (2019:142-143; 2007:67), our human-centred mindset is precisely the cause of our fateful predicament. We have not learned our lesson, irrespective of the suffering and destruction we caused. We are reluctant to acknowledge that everything that exists is interdependent and interrelated. Those speaking out against sin against environment sin are often accused of "ecological terrorizing or political fear-mongering". There is thus an incorrect understanding of sin, or more correctly, a denial of sin, which in itself represents a 
form of human pride. Deniers and disdainers clearly possess a distorted understanding of sin and stewardship, and greed and free will. For them, "environmentalism has become a conspiracy against commerce and the freedom to consume whatever we want whenever we want" (Chryssavgis, 2019:164-166).

Denial takes on various forms (Chryssavgis, 2019:173), including denying responsibility or shifting the blame for our sins. Refusing to admit sin results in, what the patristics refer to as, "closure of affections" (Chryssavgis, 1994:89-90). Considering the ecological crisis, some condemn science, while the majority denies its consequences. People are either too sceptical or sluggish to respond appropriately. Some might be over-critical of ecological issues, dismissing it as merely political or fashionable, while others are over-cautious of scientific information of which they are uniformed or in denial. Cosmic problem awareness threatens our "cosy" lives and induces fear, leading to a loss of coherence and failure to properly relate to the cosmos (Chryssavgis, 2017:274; 2007:3). As Chryssavgis (2019:173) states, there is simply "too much at stake: If we take seriously ... the issues before us, then our lifestyles would ... be immediately ... disturbed. It is far more convenient to presume guiltlessness."

Many people deny the climate change reality, regarding it a mere hoax or deeming it reversible following a more sustainable or moral way (Chryssavgis, 2019:123). Many might agree that a more refined capitalism is the solution, yet it would be absurd to believe that the crisis can be resolved through the same logic that created it in the first place (Chryssavgis, 2019:131). We need to prevent falling back into lifestyles of complacency. Climate action that is merely "climate solutions that adhere to market logic" is not the answer, as Chryssavgis (2019:133) states:

It is not just a matter of emphasizing geo-engineering or antipollution measures, of fracking natural gas or genetically modifying crops, or even of increasing nuclear or solar power. The issue is neither securing a more moderate, more palatable consumerism; nor discovering a mitigated, more restrained development (Chryssavgis, 2019:133).

Chryssavgis (2019:133) suggests a much more radical, revolutionary reformation, as we cannot be "more concerned about reflecting Caesar than Christ" and allow our hearts to be "moved more by the markets than the mystics" (Chryssavgis, 2019:153). Disdainers purely focus on the economic impact of environmental solutions and regard theologians unknowledgeable about economic issues (Chryssavgis, 2019:167). They perceive environmental concern "inversely proportional to our effectiveness in transfiguring the environment" (Chryssavgis, 2019:174), and urge "religion to stick to ethics and doctrine instead of interfering in the work of scientists and economists" (Chryssavgis, 2019:152).

The earth's present condition serves as continual reminder of our denial, however, as Chryssavgis (2019:124) observes, "[W]e stubbornly refuse to accept that our comfortable lives ... are in any way responsible". He refers to a few ecological tragedies and provocatively asks: "How can we, as intelligent human beings, believe that a century of pumping oil-fired pollution into the atmosphere has no ramifications?" In another example, Chryssavgis (2019:150) refers to United States "culture wars" that classify any association with environmental protection under the same banner as feminist and gay rights, abortion, and gun control - normally supported by the Democratic Party and usually opposed by the Republican Party.

As Chryssavgis (2019:123; 2003a:30) maintains, there is a price to pay for the destruction we caused. Authentic change is needed, because "sentimental slogans or recycling programs" will not solve anything. Creation care encompasses much more than just choosing to do things differently, as we often convince ourselves (Chryssavgis, 2019:130). Chryssavgis (2019:173) believes it might be possible to convince individuals and institutions to adopt "green" principles and methods, even to the level of incurring financial loss, yet overcoming ignorance and arrogance is a complex task. Radical changes in spiritual healing and social justice are required. All of these indicate that it is more an issue of choices than customs, so denial is the easier option. 


\section{Alternatives}

Chryssavgis (2019:123-124; 2003a:30) believes that contemplating the cross overcomes denial and disdain, implying that creation is treated in a respectful manner through repentance, resignation, and restoration. Representing ascetism, the cross directs the way toward selfdiscipline and self-sacrifice, leading to accepting responsibility for one's actions and one's world and one's actions: "[T]he conscious awareness of our own sin is an opening to grace ... empowering us to overcome the stifling restrictions of sin and death ... [and] assume responsibility for all (Chryssavgis, 1994:90).

Through "repentance for our callous disrespect" we confess our sins - our self-centredness and guilt for abusing the earth's resources (Chryssavgis, 2010:220). Like Jonah who repented of his disobedience and followed God's instruction, we too need to follow the unavoidable, essential way of ascetic renunciation and resignation (Chryssavgis, 2019:129). Chryssavgis (2019:124) holds we need to renew, what Karl Rahner dubs our "spiritual senses" and become new creatures, relearning "how to notice and feel, how to hear and smell, as well as how to taste and touch". The social consequences of renunciation are noticeable: we learn to share, use resources respectfully, and lead simple lifestyles (Chryssavgis, 2010:220).

According to Chryssavgis (2019:133), environmental in-action and awareness are excellent starting points for ecological correction. Halting what we are doing grants us fresh "in-sight" into our environment. We surrender the urge for unrestrained progress and development, and alternatively focus on sustainable ways of living. Chryssavgis (2019:134) believes perceiving our world in other, greener ways besides through market lenses is indeed a possibility, and a different, new economy is realised. It is about choosing how authentically human we want to be - choosing "between good and evil, between life and death" (Deuteronomy 30:14) - and developing a worldview involving permanent creation solutions based on spiritual choices and ethical values instead of "short-term, make-shift or band-aid" ones.

Chryssavgis (2019:166) advocates a sacramental worldview: embracing personal communion and humaneness rather than individual consumption and financial profits. Overcoming denial implies emphasising environmental change synonymous to religious "transformation" or "conversion". Firstly we should humbly acknowledge our own wrongdoing and its role in the current predicament by reflecting on our ways of living. Our worldview must be transformed: we need to convert our hearts and mindsets. All of this is necessary for altered lifestyles and attitudes to regulate or reverse the ecological crisis (Chryssavgis, 2019:175-176; 2007:2).

In finding a diverse range of solutions, Chryssavgis (2019:177) looks to cosmic liturgy with its far-reaching perspective - on humans as curious, adventurous, and inventive creatures, and the appropriate use of resources through creativity and technology. This entails practical solutions that work with nature and not against it. Ultimately it is about being aware, accountable and choosing wisely in our daily interactions. He lists some ideas and resources available for environmentally concerned individuals, groups, organisations, and communities. On the individual level, for example, a significant difference can be made by becoming sensitive to what we use (e.g. the type of energy, heating, etcetera), what can be re-used (e.g. bags, paper, cutlery, glassware, etcetera), what is wasted (e.g. water, electricity, energy, etcetera), and what can be done (e.g. supporting local manufacturers and products). Chryssavgis (2010:221) concludes: "Responsibility is our challenge, our choice. Having renounced whatever clutters our mind and our life, and after repenting of our wastefulness, we can direct our lives in love and reverence towards creation and Creator".

\section{Conclusion}

Chryssavgis remarkably contributes to contemporary environmental discourse. Theologically rich, his work highlights critical issues and also encompasses diverse solutions to our daily ecological challenges. Rasmussen (2002:103) comments that his "writing is elegant and 
economic at the same time". Writing from an Orthodox perspective, Chryssavgis skilfully utilises Christian principles, practices, and resources to present a meticulously constructed vision as appropriate response to our contemporary crisis. His sacramental worldview represents a beacon of hope and could be the starting point towards healing creation's shattered image.

Grounded in Orthodox beliefs and traditions, specifically the traditions of ascetism and sacramentalism whereby the earth is regarded a sacrament, Chryssavgis perceives all else that stands in opposition to this notion as ecological sin. One may, however, argue that his role as clergyman and spokesperson for the Orthodox Church may impede interfaith dialogue, as well as scientific, economic, and political engagement. In addition, Chryssavgis' extensive focus on the ascetic tradition may be criticised for not also reflecting its harmful elements, which Ruether (1994:188) identifies as supporting hostility towards women, the body, and the material world. Afterlife is considered more significant than earthly existence, implying reinforcement of flight from and neglect of the earth. This, however, is understandable considering ascetism representing a crucial aspect of Chryssavgis' ecotheology.

In the view of Dudley (2019:52-53), urbanisation, that Chryssavgis believes "reduces creation to a cycle of production and consumption", is an important modern-day facet that the latter does not directly address. Dudley (2019:53) argues that he does not refer to "the redemption and renewal of the city", despite Patriarch Bartholomew's 1995 symposium on the Book of Revelation and the environment. He also states that Chryssavgis refers to the Desert Fathers and Mothers standing "like trees on a busy city street, purifying and refreshing through their powerful and prayerful presence" but offers no practical means "through which great cities might be purified and refreshed".

Chryssavgis' work, however, is highly acclaimed for making the Desert Fathers and Mothers' ascetic spiritualities and the Greek Fathers' philosophies and theologies accessible and linguistically comprehensible. His compilation of these ancient wisdoms is an exceptional resource for both general and scholarly research, contextualised in a manner that appeals to a wide audience. Petrakis (2010:254) commends his work for bringing "the desert to the city" and also for "its application to modern issues and concerns in line with ... the environment".

Identifying the roots of our ecological predicament, Chryssavgis calls those denying the earth's crisis to accountability, whether scientists or religious leaders. Critically analysing the issue with boldness, he "faces squarely the shattered image of the creation now being deformed in the image of human sinfulness", as Rossi (2000) pinpoints. Chryssavgis confidently tackles the issue of denial and disdain, unlike many who ignore or wilfully disregard this noteworthy topic in environmental discourse. Zizioulas (2019:xi) states: "He has proved persistently critical of dismissing climate change as political or superficial but also passionately sensitive to the need for radical change in our attitudes and lifestyles". Chryssavgis thus acknowledges the church's traditional focus on human salvation, but also advocates its instrumental role in preaching cosmic salvation to establish such transformation.

Many agree that Chryssavgis' ecotheology appeals to a broad audience. His notions of an ascetic and sacramental worldview encourage individual and social transformation, profoundly influencing people's beliefs, choices and practices. Janus (2019) applauds Chryssavgis' work for being deeply rooted in the Orthodox tradition, while simultaneously highlighting "aspects of the same treasure Western Christianity holds dear". Rasmussen (2002:105) makes this remarkable statement:

What Chryssavgis has achieved ... is what now stands as a task for representatives of Christianity's other deep traditions; namely to tap those traditions for their Earth-honouring potential where that exists, and to be part of their conversion to Earth, as dynamic, living traditions, where that does not.

Rossi (2000) comments that Chryssavgis' work is presented in an "attractive, irenic and winsome way that it should appeal across the denominational board" and that "every pastor, every Christian in every denomination ... every member of the Orthodox Church", and every 
person who is faithful in caring for and preserving creation has much to learn from it.

\section{References}

Aquinas, (St.). T. (1991). Summa Theologica: A Concise Translation, Christian Classics: Allen, Texas.

Barth, K. (1958). Church Dogmatics, Vol III/1: The Doctrine of Creation, T. \& T. Clark: Edinburgh.

Barth, K. (1960). Church Dogmatics, Vol III/3: The Doctrine of Creation, T. \& T. Clark: Edinburgh.

Berry, W. (1991). The Unforeseen Wilderness, North Point Press: San Francisco.

Berry, W. (2009). The Gift of Good Land, Counterpoint: Berkeley.

Chryssavgis, J (2017). The Face of God in the World. In J. Hart (Ed.), The Wiley Blackwell Companion to Religion and Ecology, John Wiley \& Sons: Oxford.

Chryssavgis, J. (1994). "Sin and Grace-An Orthodox Perspective", Colloquium 26(2), 79-93.

Chryssavgis, J. (2003b). In the Heart of the Desert, Bloomington, Indiana: World Wisdom.

Chryssavgis, J. (2006). The Earth as Sacrament. In R. S. Gottlieb (Ed.), The Oxford Handbook of Religion and Ecology, Oxford University Press: Oxford.

Chryssavgis, J. (2007). Beyond the Shattered Image, Light \& Life Publishing: Minneapolis, Minnesota.

Chryssavgis, J. (2010). A New Heaven and a New Earth: Orthodox Theology and an Ecological World View, The Ecumenical Review, Vol 62(2), 214-222.

Chryssavgis, J. (2019). Creation as Sacrament, T \& T Clark: London.

Chryssavgis, J. (Ed.) (2003a). Introduction. Cosmic Grace, Humble Prayer. Grand Rapids, MI: Eerdmans.

Cloete, N. (2013). Hamartology and Ecology: A Critical Assessment of Dietrich Bonhoeffer's View on the Nature of Sin, Masters Dissertation: UWC.

Cloete, N. (2021). Hamartology and ecology: An assessment of Aruna Gnanadason's contribution to the contemporary debate, Pharos Journal of Theology, 102(30), 1-17.

Cloete, N. (2021). What on earth is wrong with the world? Unpublished PhD Dissertation: UWC.

Conradie, E.M. (2006). Christianity and Ecological Theology, Sun Press: Stellenbosch.

Conradie, E.M. (2017). Redeeming Sin? Lexington Books: London.

Dawkins, R. (2006). The God Delusion, Houghton Mifflin: Boston.

Dudley, M. (2020). Book review. Creation as Sacrament, Sage, 123(1), 52-53.

Durand, J.J.F. (1978). Die Sonde, N.G. Kerkboekhandel: Pretoria.

Engel, M.P. (1990). Evil, Sin and Violation of the Vulnerable. In S.B. Thistlethwaite \& M.P. Engel (Eds.), Lift Every Voice, Harper \& Row: San Francisco.

Heyns, J.A. 1978. Dogmatiek, N.G. Kerkboekhandel: Pretoria:

Horrell, D.G. 2010. The Bible and the Environment, Equinox: London.

Janus, A. (2019). Book review. Creation as Sacrament, Tui Motu Magazine, Issue 244, [Available online at https://hail.to/tui-motu-interislandsmagazine/publication/KrJM98L/article/gZzFDuX] (May 2020). 
Niebuhr, R. (1941/1996). The Nature and Destiny of Man, Vol. 1, John Knox: Westminster. Patel, R. (2009). The Value of Nothing, Picador: New York.

Petrakis, V. (2010). Book Review. In the Heart of the Desert, [Available online at https://academiccommons.columbia.edu/doi/10.7916/D8FB5C8J] (February 2020).

Rasmussen, L. (2002). Book Review. Beyond the Shattered Image, Koninklijke, Brill NV, Leiden, Worldviews 6, 102-104.

Rossi, V. (2000). Book Review. Beyond the Shattered Image, [Available online at http://www.orth-transfiguration.org/resources/library/practical-help/book-review-beyondshattered-image/] (February 2020).

Ruether, R.R. (1994). Gaia and God, Harper-Collins: New York.

Santmire, H.P. (1985). The Travail of Nature, Fortress Press: Philadelphia.

White Jr., L. (1967). The Historical Roots of Our Ecological Crisis, Science, 155, 1203-7.

Williams, R.R. (1985). Sin and Evil. In P.C. Hodgson \& R.H. King (Eds.), Christian Theology, Fortress: Philadelphia, 194-219.

Zizioulas, J. (2019). 'Foreword'. John Chryssavgis: Creation as Sacrament, T \& T Clark: London. 